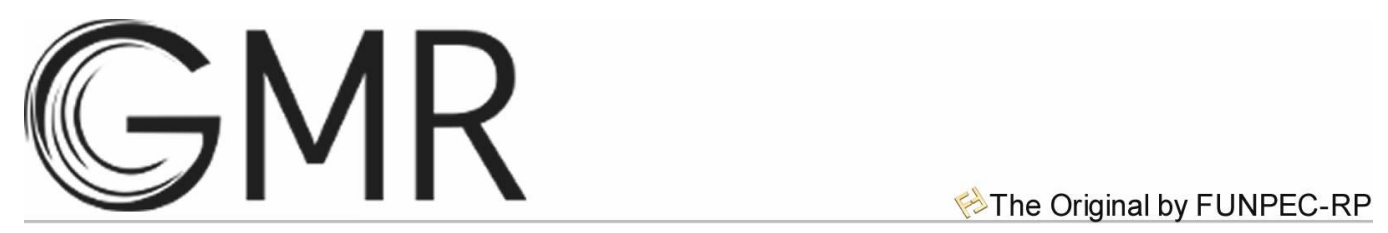

\title{
Genetic divergence between onion populations derived from three different crossing methods
}

\author{
D.L.M. Machado ${ }^{1}$, J.A. de Freitas ${ }^{2}$, J.M.Q. Luz ${ }^{1}$, G.M. Maciel ${ }^{1}$, \\ A.P.O. Nogueira ${ }^{1}$, R.R. Finzi ${ }^{1}$ and R.C. Oliveira ${ }^{1}$ \\ ${ }^{1}$ Instituto de Ciências Agrárias, Universidade Federal de Uberlândia, \\ Uberlândia, MG, Brasil \\ ${ }^{2}$ Melhorista de Cebola em Basf Sementes de hortaliças, Uberlândia, MG, \\ Brasil
}

Corresponding author: R.C. Oliveira

E-mail: robertacamargoss@gmail.com

Genet. Mol. Res. 18 (4): gmr18256

Received February 06, 2019

Accepted July 13, 2019

Published October 18, 2019

DOI http://dx.doi.org/10.4238/gmr18256

\begin{abstract}
The production of onion hybrids depends on the development of genetically pure lineages. Successive selffertilization guarantees obtaining endogenous lines quickly. However, onion undergoes a strong process of inbreeding depression when self-fertilized for several generations, which reduces plant vigor, bulb size and seed production, increasing the cost to produce hybrid seed. An estimate of the genetic distance between genotypes is a way of predicting if genetic variability is being maintained. We evaluated possible negative effects in populations due to selffertilization, compared to interbreeding between two or three plants. Eleven onion populations in different genetic segregation stages, obtained from generations that already had low or moderate inbreeding levels were included. The populations were from the breeding program of Bayer Vegetable Seeds. In order to assess the agronomic descriptors contribution for the genetic divergence, three types of crossing methods of populations were performed: selffertilization of plants, crossing between two plants and crossings between three plants, during two consecutive years (2014 and 2015). Morphological differences were detected through dissimilarity measures. The traits bulbs/plot $(28.32 \%)$, fruit fixation $(13.12 \%)$ and seed weight/umbel $(13.41 \%)$ together contributed $54.85 \%$ to the
\end{abstract}


divergence of onion genotypes. The crosses between two and three plants provided greater divergence among the genotypes, compared to self-fertilization. Economically important traits such as bulb production per plot, fruit fixation, resistance to disease caused by Alternaria porri (Pleosporaceae) and seed weight per umbel can be measured to assess divergence for appropriate selection of onion lineages among segregant populations.

Key words: Multivariate techniques; Clustering of genotypes; Canonical variables; Main component analyses

\section{INTRODUCTION}

Onion (Allium cepa) is the most widely cultivated species of the genus Allium; it is commonly used in almost all types of cuisine, in practically all countries, being consumed both raw in salads or as a condiment (Khosa et al., 2016). Onion occupies the prominent position of third most economically important crop in the world, with 92.1 million tons produced in the 2016 harvest; of this total, hybrid onions make up about $40 \%$. Brazil imports from 9 to $40 \%$ of total domestic consumption; this percentage varies depending on price and climatic conditions, which affect internal supply (Resende et al., 2007).

Hybrid heterotic gain provides superiority to pure lineages in yield, average bulb weight and growing cycle length. A major factor limiting adoption of hybrids by onion producers is the scarcity of information about agronomic performance and adaptation to Brazilian conditions (Faria et al., 2012). Hybrid onion production is expected to increase in the coming years, since in countries such as Brazil hybrid cropping is still recent and occupies only about $20 \%$ of planted area; much lower values than in countries such as the USA and Japan, where they account for 81 and $73 \%$, respectively (Almeida, 2015).

Resistance to the fungus Alternaria in new hybrids is another important attribute to consider in onion breeding programs, because Alternaria porri is one of the most destructive diseases for the genus Allium and is widespread in many regions of the world (Cramer, 2000). A major problem involves colonization by opportunistic fungi, producing secondary diseases (Abdel-Hafez et al., 2015).

Due to the potentially expansion of the hybrid onion market, various breeding programs have being initiated. As onion is an allogamous diploid $(2 n=2 x=16)$ species, with a biennial cycle, and is therefore highly susceptible to inbreeding depression by selffertilization, obtaining adequate parental lineages is one of the most expensive steps for hybrid onion seed production (Brewster, 2008). Because pedigree promotes the highest degree of homozygosity by auto-fertilization of superior individuals selected, this is the most widely used breeding method for the development of lineages. However, the main drawback of this method is boosting inbreeding depression effects, which leads to lower vigor and consequently low seed yield (Ayroles et al., 2009).

On the other hand, some studies have shown that crosses between few plants (sibs) are likely to occur in natural populations; due to either the small size of the local population or limited dispersion of the pollinators; which might promote a decrease in inbreeding depression as demonstrated by Porcher et al. (2016) and Devaux et al. (2014). Analysis of phenotypic characters can be used to assess genetic distance between populations originated 
by auto-fertilization compared to those originated by crosses between two or three pure lines

Besides, genetic distance estimation between genotypes might be useful predict if genetic variability is being maintained, as well to increase the potential for obtainment of transgressive genotypes (Cantelli et al., 2016). Multivariate statistics usually are used to analyses the combine behavior of several random variables. Phenotypic characteristics are the most common features used by plant breeders to get genetic distance measures, as such information are continuously obtained by assessments performed during selection of superior genotypes and in adaptability and stability tests.

There is a lack of information in the literature concerning segregating onion lines obtained from crosses between two or three plants (Machado et al., 2017). Therefore, due to the need for decreasing genetic depression effects caused by the inbreeding of onion genotypes, the objective of this study was the assessment of the genetic divergence of onion populations obtained by self-fertilization compared to crosses between two or three plants.

\section{MATERIAL AND METHODS}

\section{Location of study and experimental design}

This study was carried out in the Bayer Vegetable Seeds' experimental field (Latitude: $18^{\circ} 55^{\prime}$ South and Longitude: $48^{\circ} 16^{\prime}$ West, Altitude of $873 \mathrm{~m}$ ), using populations provided by this same company's breeding program in Brazil. Thirty-three onion populations in different generations of genetic segregation (F2S1, F2S2, S4 and S3) with low or moderate inbreeding levels were assessed. Agronomic traits were evaluated for a two year period (2014/2015) during vegetative and reproductive stages of development.

Experiments were carried out in a randomized block design with 100 plants per plot and three replications. Each plot consisted of five rows of one-meter length $\mathrm{x} 0.9 \mathrm{~m}$ width; plants were placed $5 \mathrm{~cm}$ apart from each other in the same row; and $20 \mathrm{~cm}$ apart on both side of rows.

The treatments consisted of onion populations obtained by three crossing techniques from 11 genetic backgrounds: 1) self-fertilization of a plant $\left[\mathrm{A}_{1}\right]$; 2) crossing between two plants $\left[\mathrm{B}_{2}\right]$; 3) crossings between three plants $\left.\left[\mathrm{C}_{3}\right]\right)$. Evaluations were performed per plot; for assessment of non-measurable traits, a scale ranging from one to nine was used.

Seeds were sown on $19^{\text {th }}$ March 2014 and the plants were transplanted on $27^{\text {th }}$ April 2014. Onion crop was irrigated and fertilized according to the recommendations during growing season. The traits evaluated in the vegetative phase were: Plant Vigor by measure leaf diameter, plant height and number of leaves, at 90 and 120 days after sowing (DAS).

At 150 DAS, the plant height, was measured in centimeters; the 'neck' diameter: measured using a rating of 1 (thick) to 9 (thin); the plant architecture was considered 1: prostrated to 9: erect; the cycle, in days from sowing to 'top down' (more than 50\% of the plants fall or in tops down). Severity of Botrytis spp. infection was evaluated according to Botrytis cinerea damage severity.

Traits evaluated after the bulb's harvest were: Skin Color, where the maximum value was attributed to bulbs with dark brown colour; Bulb Firmness; Number of Bulbs per plot; Commercial Bulbs, which comprised percentage of marketable bulbs regarding to the classes II, III and IV of bulb diameter; and Total Production, in kg/plot. After evaluations 
have been accomplished, bulbs were stored and vernalized about three months until next sowing on field for assessment of traits related to seed production. April 30, 2015, bulbs were transplanted to produce a second crop (reproductive phase).

Seed production traits assessed were: General characteristics of the plant at 30,60 and 90 days after transplanting (DAT), by evaluating the number, diameter and stem height, and umbel size on average in the plot, where the higher value got the higher mark.

Stem and umbel vigor were evaluated using a scale ranging from 1 (low) to 9 (high). The number of umbels per plot before seed harvest and the flowering uniformity per plot (number of umbels with open flowers) were evaluated using a scale ranging from 1 (less uniform) to 9 (more uniform). Fruit fixation was evaluated using a scale ranging from 1 (low fruit fixation) to 9 (high fruit fixation).

Resistance in Alternaria was assessed according to the severity of Alternaria solani damage in the plot, where 1 was equal to lowest degree of severity and 9 to the highest. Seed weight per umbel was obtained by the average weight (grams) of seed per umbel, in each plot.

\section{Univariate analyses}

The univariate analyzes were performed previous the multivariate analysis in order to quantify the variability of each trait assessed through the phenotypic coefficient of variation. Normality of variables was assessed according to Shapiro-Wilk's test.

\section{Multivariate analyses}

Multivariate techniques were used to analysis agronomic descriptors contribution in order to determinate genetic divergence of each one of the population treatments $A_{1}, B_{2}$ and $\mathrm{C}_{3}$. This analysis is consisted by the simultaneous evaluation of several traits and allows different approaches on the data, making possible to clarify both relation and the effect of each variable separately (Coimbra et al., 2007). In this work, principal component analysis (PCA) and Euclidean distances (Cruz et al., 2012) multivariate techniques were used. The hierarchical clustering method UPGMA (Unweighted Pair-Group Method Using Arithmetic Averages) was used to produce a dendrogram from the Euclidean distances matrix. Validation of clusters formed by UPGMA regarding the sets of variables assessed between groups of genotypes was determined by the Cophenetic Correlation Coefficient (CCC), which was calculated by the Mantel test (1967). In addition, genetic diversity was assessed by performing the analysis of canonical variables (Cruz et al., 2012). The relative contribution of quantitative traits was calculated according to Singh (1981) criteria. All the data obtained were analyzed using the software Genes v. 2015.5.0 (Cruz, 2013).

\section{RESULTS AND DISCUSSION}

Multivariate variance analysis (data not shown) regarding genotype $\mathrm{x}$ generation interaction effects were significant by the $\mathrm{F}$ test at $5 \%$ of probability, evidencing differences between plants treatments. Divergence between genotypes was assessed by the Euclidian distance (Table 1). This is a measure of distance available for the analysis of quantitative data, which has been regularly used to access genetic distances of organism groups. 
There were differences in measures of dissimilarity between treatments. In general, the values were higher when there was intercrossing of plants, reaching 9.60 between genotypes (BUC) x (GRxBOT-1) and 9.72 between "BUC" and "GRxBOT-3". Wanser et al. (2012) also observed differences in the divergence between genotypes in relation to the planting site by estimating the genetic variability of onion genotypes in Santa Catarina. Singh et al. (2013) found significant divergence between the same genotypes of onion subjected to short and long day conditions.

Table 1. Genetic divergence of 11 onion genotypes evaluated by Euclidian distance (D) considering three crossing methods.

\begin{tabular}{|c|c|c|c|c|c|c|c|c|c|c|c|}
\hline \multirow{2}{*}{ Genotype $^{1}$} & \multicolumn{3}{|c|}{ Cross type } & \multicolumn{5}{|c|}{ Cross type } & \multicolumn{3}{|c|}{ Cross type } \\
\hline & $\mathbf{A}_{1}$ & $\mathbf{B}_{2}$ & $\mathrm{C}_{3}$ & Genotype $^{1}$ & $\mathbf{A}_{1}$ & $\mathbf{B}_{2}$ & $\mathbf{C}_{3}$ & Genotype $^{1}$ & $\mathbf{A}_{1}$ & $\mathbf{B}_{2}$ & $\mathrm{C}_{3}$ \\
\hline$\overline{1-2}$ & 6.47 & 3.57 & 4.74 & $2-11$ & 7.23 & 8.57 & 7.98 & $5-8$ & 7.74 & 7.79 & 5.24 \\
\hline $1-3$ & 7.37 & 9.09 & 9.01 & $3-4$ & 7.30 & 7.89 & 8.87 & $5-9$ & 4.27 & 7.66 & 9.72 \\
\hline $1-4$ & 4.53 & 6.55 & 5.57 & $3-5$ & 8.59 & 9.15 & 6.75 & $5-10$ & 7.08 & 7.51 & 5.34 \\
\hline $1-5$ & 6.75 & 4.26 & 5.90 & $3-6$ & 7.61 & 8.66 & 8.36 & $5-11$ & 5.67 & 8.12 & 7.08 \\
\hline $1-6$ & 5.55 & 5.13 & 4.94 & $3-7$ & 6.84 & 6.75 & 6.52 & $6-7$ & 6.22 & 4.89 & 5.50 \\
\hline $1-7$ & 5.58 & 6.19 & 5.48 & $3-8$ & 5.79 & 5.27 & 7.48 & $6-8$ & 5.16 & 7.80 & 7.48 \\
\hline $1-8$ & 5.58 & 7.02 & 8.38 & $3-9$ & 5.45 & 5.05 & 5.50 & $6-9$ & 6.54 & 7.30 & 5.07 \\
\hline $1-9$ & 8.20 & 8.52 & 6.31 & $3-10$ & 2.58 & 4.76 & 3.72 & $6-10$ & 6.24 & 5.91 & 7.96 \\
\hline $1-10$ & 6.45 & 7.55 & 8.88 & $3-11$ & 5.34 & 4.37 & 5.58 & $6-11$ & 7.70 & 7.88 & 7.13 \\
\hline $1-11$ & 5.94 & 8.34 & 9.31 & $4-5$ & 6.19 & 7.75 & 6.40 & $7-8$ & 6.10 & 7.01 & 7.21 \\
\hline $2-3$ & 8.31 & 8.39 & 8.87 & $4-6$ & 6.09 & 8.50 & 6.37 & $7-9$ & 8.08 & 6.41 & 3.87 \\
\hline $2-4$ & 6.58 & 6.33 & 6.41 & 4-7 & 7.28 & 7.12 & 7.35 & $7-10$ & 6.15 & 4.78 & 7.02 \\
\hline $2-5$ & 5.90 & 5.03 & 5.80 & $4-8$ & 4.90 & 6.32 & 8.33 & $7-11$ & 7.46 & 6.57 & 6.83 \\
\hline $2-6$ & 7.61 & 4.82 & 5.66 & $4-9$ & 8.36 & 7.43 & 7.02 & $8-9$ & 7.66 & 5.62 & 7.06 \\
\hline $2-7$ & 8.25 & 5.64 & 5.80 & $4-10$ & 6.10 & 7.48 & 8.20 & $8-10$ & 5.00 & 5.72 & 7.15 \\
\hline $2-8$ & 7.83 & 7.36 & 8.03 & 4-11 & 4.59 & 7.56 & 9.17 & $8-11$ & 5.09 & 5.96 & 7.84 \\
\hline $2-9$ & 7.56 & 8.10 & 6.05 & $5-6$ & 8.84 & 3.63 & 5.15 & $9-10$ & 5.20 & 5.09 & 4.78 \\
\hline \multirow[t]{2}{*}{$2-10$} & 6.67 & 6.02 & 7.88 & $5-7$ & 6.18 & 9.60 & 9.32 & $9-11$ & 8.05 & 5.73 & 5.39 \\
\hline & & & & & & & & $10-11$ & 4.60 & 6.58 & 5.21 \\
\hline
\end{tabular}

* significant at $5 \%$ probability of error by the $\mathrm{F}$ test (significant at $5 \%$ of probability of error by the $\mathrm{F}$ test). $\mathrm{A}_{1}$ : selffertilization of a plant; $\mathrm{B}_{2}$ : intercrossing of two plants and $\mathrm{C}_{3}$ : intercrossing of three plants. ${ }^{1} 1=\mathrm{GRxGR} ; 2=\mathrm{IP}-1 ; 3=\mathrm{IP}-$ 2xIP-3; 4= IP-3xIP-2; 5= BUC; 6= GRxIP-1; 7= GRxBOT-1; 8= GRxBOT-2; 9= GRxBOT-3; 10= GRxBOT-4; 11= CRxBOT-1.

The lowest D-value was attributed to the genotypes IP-2xIP-3 and GRxBOT-3 (D = 2.58 ), with a lower genetic diversity between two parents, greater homozygosity is expected so that in their segregating generations there is less possibility of recovery of superior genotypes (Passos et al., 2007). It was observed tendency of decreasing genetic distance with self-fertilization, indicating that the self-fertilization slightly increased similarity between the genotypes regarding traits evaluated. However, the main factor that more likely contributed to the genotypes similarity was the narrow genetic base of onion genotypes available in Brazil.

It is pertinent to highlight that both IP-1 and IP-2xIP-3, and GRxBOT-1 and GRxBOT-2 exhibited marked genetic divergence despite these materials have been derived from selection in populations with similar backgrounds. This indicates that there may not be a direct correspondence between the genetic relationship between accessions and the expected relationship so, that other factors should be considered and not only phenotypic aspects. Despite of genetics differences highly pronounced both lines are phenotypically homogeneous regarding a specific attribute. This observation suggested that the 
morphological characteristics due its dependence of environmental conditions are independent of their genetic relation. These observations are in agreement with GonzálezPérez et al. (2015) who have reported the same on onion varieties grown in northwestern Spain.

Table 2 shows the relative contribution of each trait to genetic diversity assessed according to the $\mathrm{Sj}$ statistic proposed by Singh (1981); bulbs/plot (28.32\%), fruit fixation $(13.12 \%)$ and seed weight/umbel (13.41\%) together have contributed to $54.85 \%$ of total divergence between onion genotypes. Moreover, these finds have pointed that Alternaria resistance is as well an important trait contributing to the dissimilarity of the genotypes, which disagree with results obtained by Buzar et al. (2007). However, must be considered that these authors have assessed different traits of those presented in this work, which might have led to different results; as well the environment differences might have been influenced the pathogen development. Studies of relative contribution of characters and the observation of dissimilarities between clusters of genotypes help breeders in breeding programs. However, the potential per se of each genotype also must be considered as a criterion of selection (Mattedi et al., 2015). Machado et al. (2017) reported that Alternaria resistance also can be useful for indirect selection for seed mass per umbel.

Table 2. Relative contribution of 23 phenotypic traits to the genetic dissimilarity of 11 onion genotypes originated from three crossing methods $\left(\mathrm{A}_{1}\right.$ : self-fertilization of a plant, $\mathrm{B}_{2}$ : crossing of two plants and $\mathrm{C}_{3}$ : crossing of three plants), according to Singh statistic (1981).

\begin{tabular}{lc}
\hline Characters & Relative Contribution (\%) \\
\hline Plant vigor at 60 days & 1.34 \\
Plant vigor at 120 days & 1.68 \\
Plant height & 0.56 \\
Neck diameter & 1.30 \\
Plant architecture & 0.89 \\
Duration of the cycle & 3.45 \\
Severity of Botrytis cinerea damage & 3.12 \\
Average bulb weight & 3.45 \\
Percentage of globular bulbs & 1.34 \\
Percentage of commercial bulbs & 1.76 \\
Production of bulbs/plot & 28.32 \\
General appearance of stems at 30 days & 2.23 \\
General appearance of stems at 60 days & 2.02 \\
General appearance of stems at 90 days & 0.98 \\
Stem vigor & 0.98 \\
Umbel vigor & 2.01 \\
Number of umbels/plot & 2.24 \\
Number of plants/plot & 2.03 \\
Flowering Uniformity & 2.03 \\
Fruit Fixation & 13.12 \\
Resistance to Alternaria porri & 9.18 \\
Weight of seeds/plot & 2.56 \\
Weight of seeds/umbel & 13.41 \\
\hline
\end{tabular}

UPGMA clustering dendrogram results are shown in Figure 1. The related correlation coefficient was equal to $0.72(\mathrm{P}<0.01)$, which means that the dendrogram satisfactorily represented the information contained in the distance matrix; in this work 
groups were separated at $70 \%$ dissimilarity; the threshold was established at the point of abrupt change in the dendrogram branches, as recommended by Cruz et al. (2012).

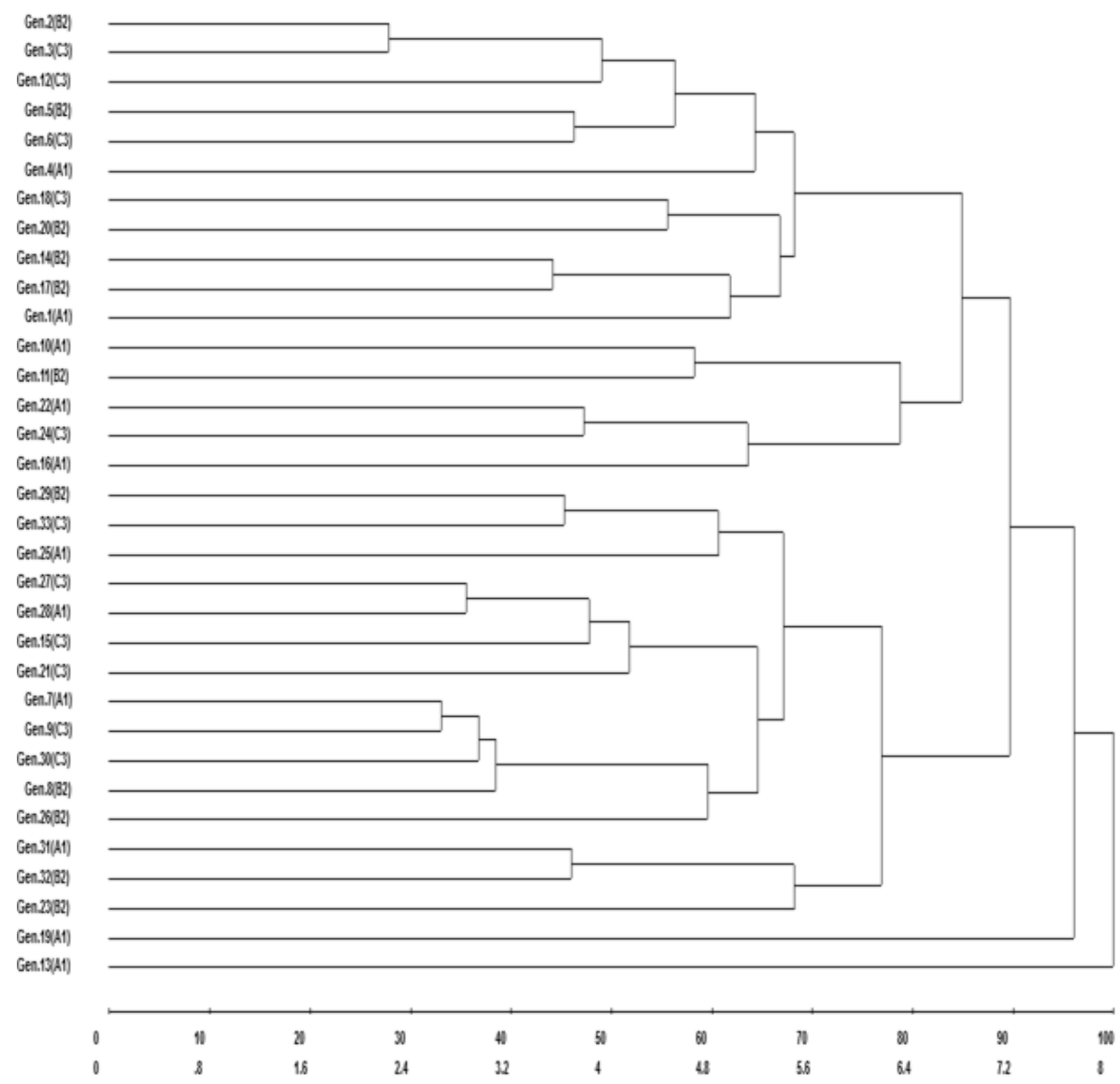

Figure 1. UPGMA dendrogram of 11 onion genotypes derived from three crossing methods (A1: self-fertilization of a plant, B2: intercrossing of two plants and C3: intercrossing of three plants), obtained by Euclidian distance matrix. Cophenetic correlation coefficient: 0.72**. Subtitle: Genotype 1, 2 and 3= GRxGR; Genotype 4, 5 and $6=$ IP-1; Genotype 7, 8 and 9= IP-2xIP-3; Genotype 10, 11 and 12= IP-3xIP-2; Genotype 13, 14 and 15= BUC; Genotype 16, 17 and 18= GRxIP-1; Genotype 19, 20 and 21= GRxBOT-1; Genotype 22, 23 and 24= GRxBOT-2; Genotype 25, 26 and 27= GRxBOT-3; Genotype 28, 29 and 30= GRxBOT-4; Genotype 31, 32 and 33= CRxBOT-1.

By examining, the UPGMA dendrogram in Figure 1 is possible observe that Groups I and IV were made up by 23 out of a total of 33; groups II was made up by GRxBOT-4 and CRxBOT-1; group III by the genotypes descendants of the CRxBOT-1, IP-1 and BUC parents. In addition, group VI composed by GRxBOT-2 and group VII by IP-1 were completely separated from each other and from the others.

Despite the onion genotypes narrow genetic base, González-Pérez et al. (2015) also have observed divergence between groups of genotypes using UPGMA algorithms. As well, Tocher method have been satisfactorily applied to expose the divergence between groups of onion genotypes (Akter et al., 2015; Khosa and Dhatt, 2015; Rivera et al., 2016). 
Genotype clustering followed two trends. First, according to the pedigree, were greater similarity among individuals with the same backgrounds was expected. Secondly, grouping tendency was according to crossing methods; there was a concentration of individuals descending from the interbreeding of plants $\left(\mathrm{B}_{2}\right.$ and $\left.\mathrm{C}_{3}\right)$ into groups I and IV. It was not possible to detect group trends, differentiating between crosses between two or three plants (Figure 1).

PCA graphic dispersion revealed six groups (Figure 2). Eigenvalues regarding the first two main components explained $88.36 \%$ of total variation. Main component 1 alone comprised $52.13 \%$ of variability. According to Cruz et al. (2012), a satisfactory interpretation of the observed variability requires that the first main components comprise at least of $80 \%$ of total variation of the characters set; that was obtained to first two main components in this work. Therefore, genetic divergence observed was satisfactory described by the graphically representation. PCA reduces the dimensionality of data containing a large set of variables. This is achieved by transforming the initial variables into a new small set of variables without losing the most important information in the original data set. These new variables correspond to a linear combination of the originals and are called principal components (Hair, 2005).

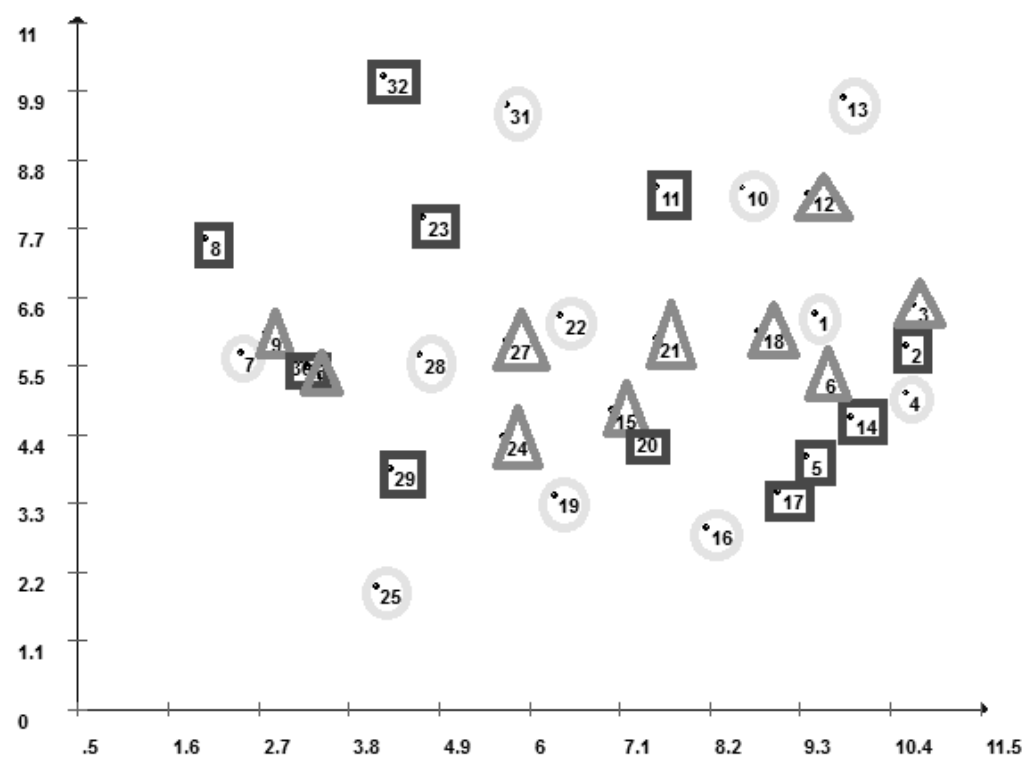

Figure 2. Principal components distribution of 11 onion genotypes derived from three crossing methods $\left(\mathrm{A}_{1}\right.$ : selffertilization of a plant, $\mathrm{B} 2$ : intercrossing of two plants and $\mathrm{C}_{3}$ : intercrossing of three plants), in a bi-dimensional plan defined by the first two main components based in 23 phenotypic traits. *Number of accesses present in each cluster revealed by Tocher's optimization algorithm, as suggested by Tocher in RAO (1952).

Therefore in this work, the initial set of 23 variables was resumed into PC1 axis corresponding the first principal direction along which the samples show the largest variation, and $\mathrm{PC} 2$ axis that was the second most important direction and it is orthogonal to the PC1 axis; the genotypes were distributed according its dissimilarity between each other, by the Toucher method. 
The clustering observed by the UPGMA method agreed with the Toucher method. Groups were formed according to the pedigree; differences between the methods were related to the separation of the genotypes according to the crossing methods (A1, B2 and C3). By observing the genotypes distribution in the scatter plot (Figure 2), it was possible to identify GRxBOT-2 and GRxBOT-4 as more divergent in the Cartesian plane, "BUC" and "GRxBOT-3". These results agree with those obtained by UPGMA, which indicates how feasible such methods are in the identification of divergent onion genotypes.

Based on pedigree analysis, we observed a shorter distance between genotypes originated from interbreeding of plants, as compared to genotypes of plants originated from self-fertilization, which reinforce the idea that crossing may have increased the divergence among the genotypes. This may have occurred, especially if the same genetic loci are contributing to the evolution of these traits, due to the increased gene flow provided by plant cross-linking. In this way, the results indicate that for a proposed solution of sib among a few plants, crosses between the different genotypes may offer segregant lineages with genetic constitutions of interest, providing less loss of vigor due to inbreeding with greater genetic divergence.

\section{CONCLUSIONS}

The crosses between two and three plants (B2 and C3) for production of segregant generations provided greater divergence among the genotypes, compared to self-fertilization (A1). Therefore, important traits such as bulb production per plot, fruit fixation, and resistance to disease caused by Alternaria and seed weight per umbel can be used to assess divergence and for selection of onion lineages among segregant populations.

\section{ACKNOWLEDGMENTS}

We thank Bayer Cropscience Vegetable Seeds for financial support and space provided for the development of this study; we also thank CAPES (Coordenação de Aperfeiçoamento de Pessoal de Nível Superior) for the scholarship granted.

\section{CONFLICTS OF INTEREST}

The authors declare no conflict of interest.

\section{REFERENCES}

Abdel-Hafez SII, Abo-Elyousr KAM and Abdel-Rahim IR (2015). Leaf surface and endophytic fungi associated with onion leaves and their antagonistic activity against Alternaria porri. Czech. Mycol. 67: 1-22.

Almeida DO (2015). Tendências da Cebolicultura Mundial para o Próximo Milênio. Informativo da Associação Nacional dos Produtores de cebola - ANACE, n.2.

Akter MS, Biswas A, Siddique SS, Hossain S, et al. (2015). Estimation of Genetic Diversity in Onion (Allium cepa L.). The Agriculturists. 13: 26-34. http://dx.doi.org/10.3329/agric.v13i1.26545

Ayroles JF, Hughes KA, Rowe KC, Reedy MM, et al. (2009). A genomewide assessment of inbreeding depression: gene number, function and mode of action. Conserv. Biol. 23: 920-930. http://dx.doi.org/10.1111/j.15231739.2009.01186.x.

Brewster JL (1994). Onions and other vegetable alliums. CAB International, Wallingford. 236p. 
Buzar AGR, Oliveira VR and Boiteux LS (2007). Estimativa da diversidade genética de germoplasma de cebola via descritores morfológicos, agronômicos e bioquímicos. Hort. Bras. 25: 527-532. http://dx.doi.org/10.1590/S010205362007000400007.

Cantelli DAV, Hamawaki OT, Rocha MR, Nogueira APO, et al. (2016). Analysis of the genetic divergence of soybean lines through hierarchical and Tocher optimization methods. Genet. Mol. Res. 15: gmr.15048836. http://dx.doi.org/10.4238/gmr.15048836.

Coimbra JLM, Santos JCP, Alves MV and Barzotto I (2007). Técnicas multivariadas aplicadas ao estudo da fauna do solo: contrastes multivariados e análise canônica discriminante. Rev. Ceres. 54: 270-276.

Cruz CD (2013). GENES: a software package for analysis in experimental statistics and quantitative genetics. Acta Sci. 35: 271-276. http://dx.doi.org/10.4025/actasciagron.v35i3.21251.

Cruz CD, Regazzi AJ and Carneiro PCS (2012). Modelos biométricos aplicados ao melhoramento genético. 4ed. Viçosa, MG: UFV. 514p.

Cramer CS (2000). Breeding and genetics of Fusarium basal rot resistance in onion. Euphytica. 115: 159-166. https://doi.org/10.1023/A:1004071907642.

Devaux C, Lande R and Porcher E (2014). Pollination ecology and inbreeding depression control individual flowering phenologies and mixed mating. Evolution. 68: 11. https://doi.org/3051-3065. 10.1111/evo.12507.

Faria MV, Morales RGF, Resende JTV, Zanin DS, et al. (2012). Desempenho agronômico e heterose de genótipos de cebola. Hort. Bras. 30: 220-225. http://dx.doi.org/10.1590/S0102-05362012000200007.

González-Pérez S, Mallor C, Garcés-Claver A, Merino F, et al. (2015). Exploring genetic diversity and quality traits in a collection of onion (Allium cepa L.) landraces from north-west Spain. Genetika. 47: 885-900. https://doi.org/10.2298/GENSR1503885G.

Hair JF, Anderson RE, Tatham RL and Black W (2005). Análise multivariada de dados. Porto Alegre, Bookman.

Khosa JS, McCallum J, Dhatt A and Macknight RC (2016). Enhancing onion breeding using molecular tools. Plant Breeding. 135: 9-20. https://doi.org/10.1111/pbr.12330.

Khosa JS and Dhatt AS (2015). Genetic diversity for morphological and biochemical traits in bulb onion. Indian J. Hortic. 72: 143-146. https://doi.org/10.5958/0974-0112.2015.00027.4.

Machado DLM, Freitas JA, Luz JMQ, Maciel GM, et al. (2017). Phenotypic, genotypic, and environmental correlations between characters in onion segregate populations obtained under different generations. Genet. Mol. Res. 16: gmr16039838. https://doi.org/10.4238/gmr16039838.

Mantel N (1967). The detection of disease clustering and a generalized regression approach. Cancer Res. 27: 209-212.

Mattedi AP, Laurindo BS, Silva DJH, Gomes CN, et al. (2015). Selection of okra parents based on performance and genetic divergence. Afr. J. Biotechnol. 14: 3044-3050. https://doi.org/10.5897/AJB2015.14952.

Passos AR, Silva SA, Cruz PJ, Rocha MM, et al. (2007). Divergência genética em feijão-caupi. Bragantia. 66: 579-586. http://dx.doi.org/10.1590/S0006-87052007000400007.

Porcher E and Lande R (2016). Inbreeding depression under mixed outcrossing, self-fertilization and sib-mating. Evol. Biol. 16: 105. https://doi.org/ 10.1186/s12862-016-0668-2.

Resende JTV, Pires DB, Camargo LKP and Marchese A (2007). Desempenho produtivo de cultivares de cebola em Guarapuava, Paraná. Ambiência. 3: 193-199.

Rivera A, Mallor C, Garcés-Claver A, García-Ulloa, et al. (2016). Assessing the genetic diversity in onion (Allium cepa L.) landraces from northwest Spain and comparison with the European variability. New Zeal. J. Crop Hort. 44: 103-120. https://doi.org/10.1080/01140671.2016.1150308.

Singh SR, Ahmed N, Lal S, Ganie SA, et al. (2013). Determination of genetic diversity in onion (Allium cepa L.) by multivariate analysis under long day conditions. Afr. J. Agric. Res. 8: 5599-5606. https://doi.org/10.5897/AJAR2013.7969.

Singh D (1981). The relative importance of characters affecting genetic divergence. Indian J. Genet. Pl. Br. 41: 237-245.

Wamser GH, Arruda B, Stinghen JC, Rozzetto DS, et al. (2012). Caracterização e estimativa da variabilidade genética de genótipos de cebola. Hort. Bras. 30: 327-332. http://dx.doi.org/10.1590/S0102-05362012000200024. 